\section{Influence of \\ Trickle \\ Irrigation \\ Emitter \\ Placement on \\ Yield and Grade \\ Distribution of \\ Potatoes}

\author{
R.E. Zartman', \\ L. Rosado-Carpio ${ }^{2}$, and \\ R.H. Ramsey ${ }^{3}$
}

Additional index words. soil temperature, irrigation frequency

Summary. A 2-year study on the influence of trickle irrigation on the yield response of potato (Solanum tuberosum L. cv. Norgold Russet 'M') was conducted at Lubbock, Texas. The objective was to evaluate the effects of trickle emitter placement on yield of \#1, \#2, marketable, cull, small, and total tubers. Trickle emitter lines were positioned 1) on the soil surface, 2) with the tuber pieces (4-inch depth), and 3) at S-inch depth. Irrigation was applied daily to replenish the water lost the previous day based on pan evaporation and crop coefficients. Marketable tuber yield was $\approx 8.9$ to 11 tons/acre for all irrigation treatments. In both years, the proportion of misshapen potatoes (culls) was significantly greater for the S-inch depth irrigation treatment than for the surface or 4-inch depth treatments $(2.9$ vs. 0.71 and 0.67 tons/acre and 3.3 vs. 0.89 and 1.16 tons/acre, respectively). The misshapen tubers were directly influenced by trickle emitter placement and indirectly influenced by temperature differences within the tuber zone.

${ }^{I}$ Professor, Dept. of Agronomy, Horticulture, and Entomology.

${ }^{2}$ Graduate Research Assistant, Dept. of Agronomy, Horticulture, and Entomology.

${ }^{3}$ Associate Professor of Civil Engineering.

Journal Article no. T-4-290 from the Agronomy, Horticulture, and Entomology Dept. of Texas Tech Univ., Lubbock, TX 79409-2122.
$\mathbf{P}$ otatoes are sensitive to water stress, with water supply influencing quality as well as yield. Trickle irrigation allows a producer flexibility in timing, placement, and quantity of irrigation. Potential advantages of trickle irrigation are:

1 ) increased beneficial use of available water

2) enhanced plant growth and yield

3) reduced salinity hazards

4) improved fertilizer and chemical applications

5) limited weed growth

6) decreased energy requirement compared to sprinkler systems

7) improved cultural practices

8) reduced operation labor through automation

(Bucks et al., 1982; Howell et al., 1980; Nakyama and Bucks, 1986).

Trickle irrigation is not, however, a panacea for irrigation. Its potential disadvantages are:

1) increased maintenance requirements

2) greater salt accumulation near plants

3) restricted root development

4) increased system costs (Bucks et al., 1982; Howell et al., 1980; Nakyama and Bucks, 1986). High-frequency trickle irrigation has been used successfully in the southeastern United States (Phene and Sanders, 1976).

Many comparisons have been made between potatoes produced by drip irrigation and those grown by other methods. Sammis (1980) compared the effect of sprinklers, drip, biwall tubing, subsurface, drip system buried 4 inches, and furrow irrigation methods on yield and quality of 'Kennebec' potatoes. He concluded that the lowest irrigation ratios (applied water divided by consumptive use) under nonlimiting water conditions were achieved by drip and subsurface irrigation for two growing seasons. Hassan (1985) used different types of drip emitters (spaghetti, layflat, and seep hose) on bare and mulched soil, and found that potato yields were significantly greater with the spaghetti and lay-flat drip systems than with furrow and seep hose irrigation. The differences were attributed to differences of the soil thermal regime between the two types of irrigation. Shalhevet et al. (1983), comparing 
Table 1. Irrigation and rainfall during four potato growth stages in 1987 and 1988.

\begin{tabular}{|c|c|c|c|c|}
\hline \multirow[b]{2}{*}{$\underline{\text { Stage }}$} & \multicolumn{2}{|c|}{1987} & \multicolumn{2}{|c|}{1988} \\
\hline & Irrigation & Rain & Irrigation & Rain \\
\hline & \multicolumn{4}{|c|}{ Inches } \\
\hline Initial & 2.1 & 0.7 & 2.6 & 0.7 \\
\hline Crop development & 1.7 & 2.2 & 3.1 & 1.1 \\
\hline Midseason & 3.8 & 2.4 & 6.1 & 0.8 \\
\hline Late season & 1.1 & 2.7 & 0.9 & 2.2 \\
\hline Total & 8.7 & 8.0 & 12.7 & 4.8 \\
\hline
\end{tabular}

drip and sprinkler irrigation methods, found no difference in marketable potato yield. However, the percentage of marketable tubers declined when $<82$ $\mathrm{cm}$ of water was applied by drip irrigation.

Reduced potato yield and quality due to high soil temperature have been reported by several researchers. Optimum soil temperature ranges have been reported to be: 15 to $18 \mathrm{C}$ (Doorenbos and Kassam, 1979); 15 to 22C (Manrique and Uehara, 1984); and 15 to 23C (Yamaguchi et al., 1964). The effects of soil temperature on potato growth and yield also vary with the growth stage of the crop (Epstein, 1966). When the mean maximum soil temperature exceeded $21.7 \mathrm{C}$, and the soil matric potential changed from -0.037 to $-0.057 \mathrm{MPa}$ total tuber yield declined 6\% (Box et al., 1963). Higher yield and more-uniform tubers were produced between 15 to $23 \mathrm{C}$ than under soil temperatures below and above this range (Yamaguchi et al., 1964). When soil temperature ranged between 26 and 29C, misshapen 'Russet Burbank' tubers developed (Yamaguchi et al., 1964).

The soil water content can influence soil temperature regime. The soil surface warms up more slowly and exhibits smaller amplitude in the daily temperature variation when wet than when dry (Thorne and Thorne, 1979). Careful management of irrigation is essential, not only for optimum water supply to potatoes but also because irrigation can significantly decrease the soil temperature by evaporative cooling (Wierenga et al., 1971). Frequent irrigations that kept the soil matric potential at $-0.025 \mathrm{MPa}$ reduced soil temperature by an average of $3.5 \mathrm{C}$ (Prihar et al., 1979). Different soilwetting patterns resulting from furrow and drip irrigation methods cause significant differences in the soil thermal regime and differences in potato yield (Hassan, 1985).

The objective of this 2-year trickle irrigation study was to evaluate the influence of emitter placement on yield and grade of potatoes.

\section{Materials and Methods}

'Norgold Russet M' potatoes were planted on 14 Mar. 1987 and 11 Mar. 1988 in an Amarillo fine sandy loam soil (fine loamy, mixed, thermic aridic Paleustalf) in Lubbock, Texas. Seed pieces $(2 \mathrm{oz})$ were planted at the 4inch depth, 9 inches apart in 40-inch bedded rows. Preplant fertilization was applied annually, based on soil tests at a rate of $447 \mathrm{lb} / \mathrm{acre}$ of $35 \mathrm{~N}-10 \mathrm{P}-0 \mathrm{~K}$. Trifluralin (a,a,a-trifluoro-2,6dinitro$\mathrm{N}$, N-dipropyl-p-toluidine) was sprayed and incorporated annually at 1 pint/ acre to control weeds. The plants were sprayed with Maneb (manganese ethylene bisdithiocarbamate at $2 \mathrm{lb}$ a.i./ acre) and with Permethrin [(3-phe- noxyphenyl) methyl $( \pm)$ - cis trans-3(2,2-dichloroethenyl)-2,2-dimethyl cyclopropane-carboxylate] at a rate of $12 \mathrm{oz} / \mathrm{acre}$ as needed to control early blight and insects.

The experiment consisted of three treatments based on depth of trickle irrigation emitter. Emitters were placed: 1) on the surface of the beds, 2) at the 4-inch depth, or 3) at the 8inch depth. The g-inch-depth tubing was installed preplant, while 4-inchdepth tubing was placed in the tuber row before covering the seed pieces. Surface trickle irrigation lines were installed after planting. Each experimental unit consisted of three rows 28 yards long; these were replicated four times (blocks). The experiment was arranged in a randomized completeblock design. The irrigation water (EC $=0.3 \mathrm{dSžm}^{-1}$ ) was applied through a Chapin Twin-wall hose. This tubing had emitters 9 inches apart and a flow rate of $0.5 \mathrm{~g} / \mathrm{min}$ per $100 \mathrm{ft}$ of hose at pressure of 10 psi.

Water was applied daily to replenish water removed as determined using daily evaporation from a class ' $\mathrm{A}$ ' evaporation pan with appropriate pan and crop coefficients. The pan coefficient used for estimating reference crop evapotranspiration varied with prevailing daily wind speed and relative humidity of the air (Doorenbos and Kassam, 1979). The crop coefficients (Kc) relate reference crop evapotranspiration to potato evapotranspiration. The various potato development stages were determined visually. The Kc values were as follows: 1) initial-stage duration of 25 days with $\mathrm{Kc}=0.4 ; 2$ ) cropdevelopment stage of 30 days, with $\mathrm{Kc}$ linearly increasing from 0.4 to $1.15 ; 3$ ) midseason stage of 30 days in 1987 and 25 days in 1988 , with $\mathrm{Kc}$ at a value of 1.15; and 4) late-season stage with a duration of 18 days in 1987 and 12 days in 1988, with Kc steadily decreasing until it reached a value of 0.6 . The

Table 2. The influence of trickle irrigation emitter placement on yield of 'Norgold Russet M' Potato.

\begin{tabular}{|c|c|c|c|c|c|c|c|c|}
\hline \multirow[b]{2}{*}{ Year } & \multirow[b]{2}{*}{ Emitter placement } & \multicolumn{6}{|c|}{$\begin{array}{c}\text { Yield (tons/acre) } \\
\end{array}$} & \multirow[b]{2}{*}{ Marketable $(\%)$} \\
\hline & & No. 1 & No. 2 & Marketable & Small & Cull & Total & \\
\hline \multirow[t]{3}{*}{1987} & Surface & 7.85 & 3.0 & 10.9 & 1.2 & 0.67 & 12.8 & 85.3 a \\
\hline & 4 inches & 7.63 & 4.0 & 11.6 & 1.3 & 0.71 & 13.6 & 85.6 a \\
\hline & 8 inches & 6.56 & 3.3 & 9.8 & 1.3 & 2.9 & 14.0 & $70.3 \mathrm{~b}$ \\
\hline \multirow[t]{3}{*}{1988} & Surface & 6.07 & 3.5 & 9.5 & 0.67 & 0.089 & 11.8 & 80.8 a \\
\hline & 4 inches & 5.44 & 4.4 & 9.8 & 0.85 & 1.2 & 11.8 & $83.0 \mathrm{a}$ \\
\hline & 8 inches & 6.02 & 2.8 & 8.8 & 1.2 & 3.3 & 13.2 & $66.6 \mathrm{~b}$ \\
\hline
\end{tabular}

${ }^{2}$ Means within a column by year followed by the same letter are not significantly different according to Duncan's multiple range test $(P<0.05)$. 
Table 3. Mean and maximum tensiometer readings as function of trickle emitter placement.

\begin{tabular}{lccc}
\hline $\begin{array}{l}\text { Emitter } \\
\text { location }\end{array}$ & $\begin{array}{c}\text { Tensiometer depth } \\
\text { (inches) }\end{array}$ & \multicolumn{2}{c}{ Tensiometer reading (centibars) } \\
\cline { 2 - 4 } Surface & 6 & 11 & Mean \\
& 12 & 12 & 15 \\
& 18 & 15 & 18 \\
4 inches & 24 & 18 & 22 \\
& 6 & 11 & 13 \\
& 12 & 13 & 17 \\
8 inches & 18 & 14 & 16 \\
& 24 & 18 & 21 \\
& 6 & 12 & 18 \\
& 12 & 10 & 15 \\
& 18 & 12 & 17 \\
\hline
\end{tabular}

length of growing season (103 days in 1987 and 92 days in 1988) is similar to that for "Fall-planting warm winter desert climates" (Doorenbos and Pruitt, 1977). The quantities of irrigation and rainfall are presented in Table 1.

One replicate of each treatment was monitored for changes in soilwater potential with tensiometers and for soil temperature with thermocouples. A duplicate set of tensiometers was installed in the bed at 6-, 12-, 18-, and 24-inch depths and read daily immediately after irrigation began. Duplicate copper-constantan thermocouples were installed at 1-, 4-, 6-, and 8-inch depths. Air temperature was measured in the canopy 2 inches above the ground surface. Daily mean soil temperatures were determined by averaging the thermocouple readings for each treatment and depth.

Tubers were mechanically harvested from a 17-ft section of the center row of each plot on 24 July 1987 and 6 July 1988. Total tuber yields, the yields of graded tubers (Federal Register, 1970), and specific gravities were determined by hydrometer immediately after harvest. Data were evaluated using analysis of variance (ANOVA) and Duncan's multiple range test.

\section{Results and Discussion}

All tubers had good internal quality, and tubers from each plot had average specific gravity values of $\approx 1.06$. ANOVA of these yield data showed no significant differences $(P=0.05)$ due to treatment in either year among emitter depths in yields of \#1, \#2, marketable, small, or total tubers (Table 2). However, there was significantly greater cull (misshapen rather than damaged) tuber yield $(\mathrm{P}=0.05)$ for the 8-inch emitter depth treatment than for the surface or 4-inch treatments. When comparing percentage ofmarketable tubers, the 8-inch emitter treatment gave significantly lower values than the other two treatments (Table 2). This difference was due to the increased cull tuber production, not decreased total tuber production capacity. Most of the cull tubers were culled because of their shape. The total tuber yields were similar for all three treatments.

To explain the influence of irrigation treatment on cull tuber yield and percentage of marketable tubers, soil matric potential and temperatures were measured during the growing season. The mean and maximum soil-manic potentials at 6-, 12-, 18 and 24-inch depths are reported in Table 3. With the similarity of values, an indirect treatment effect was responsible for

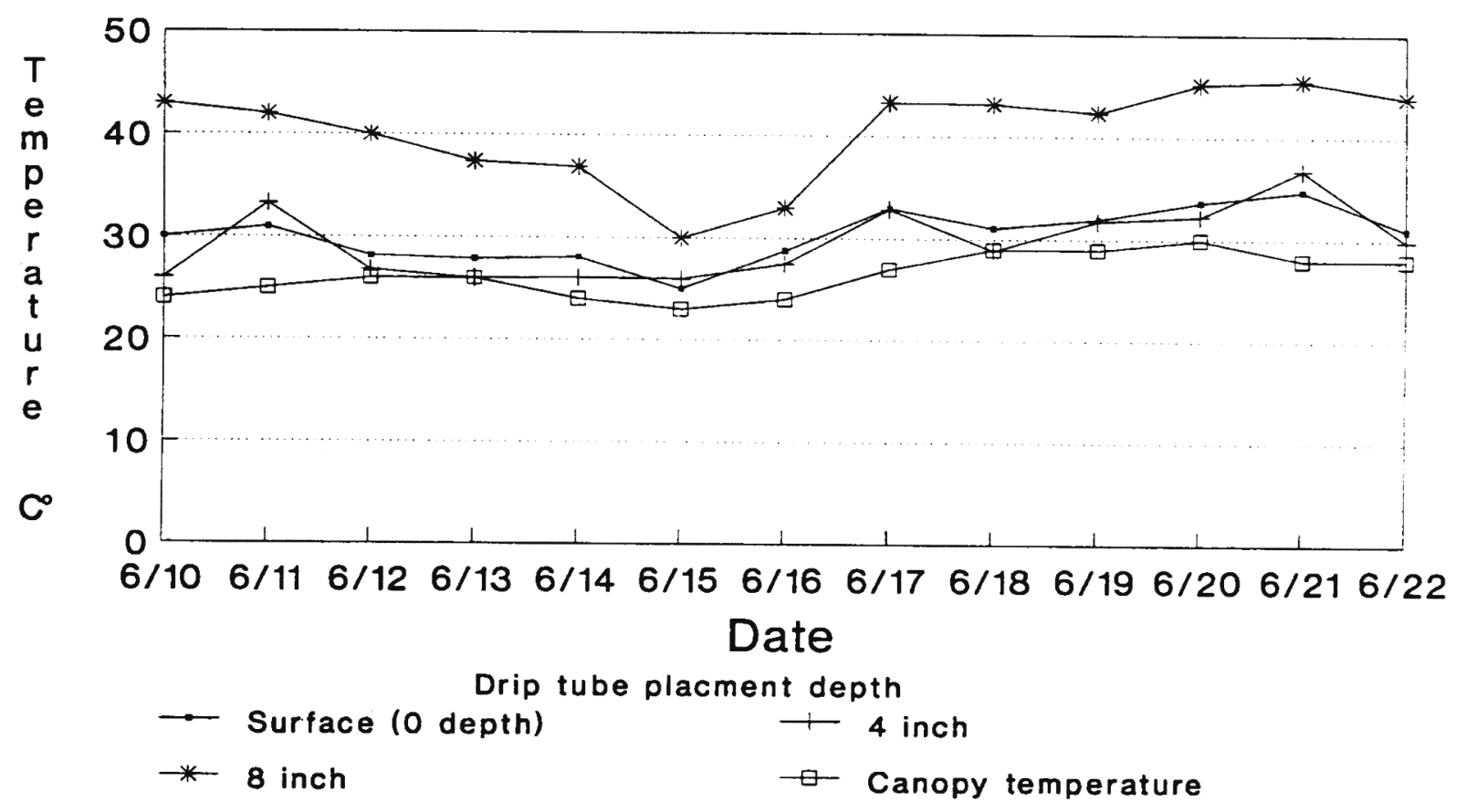

Fig. 1. Daily mean canopy temperature and soil temperature at 1-inch depth. 


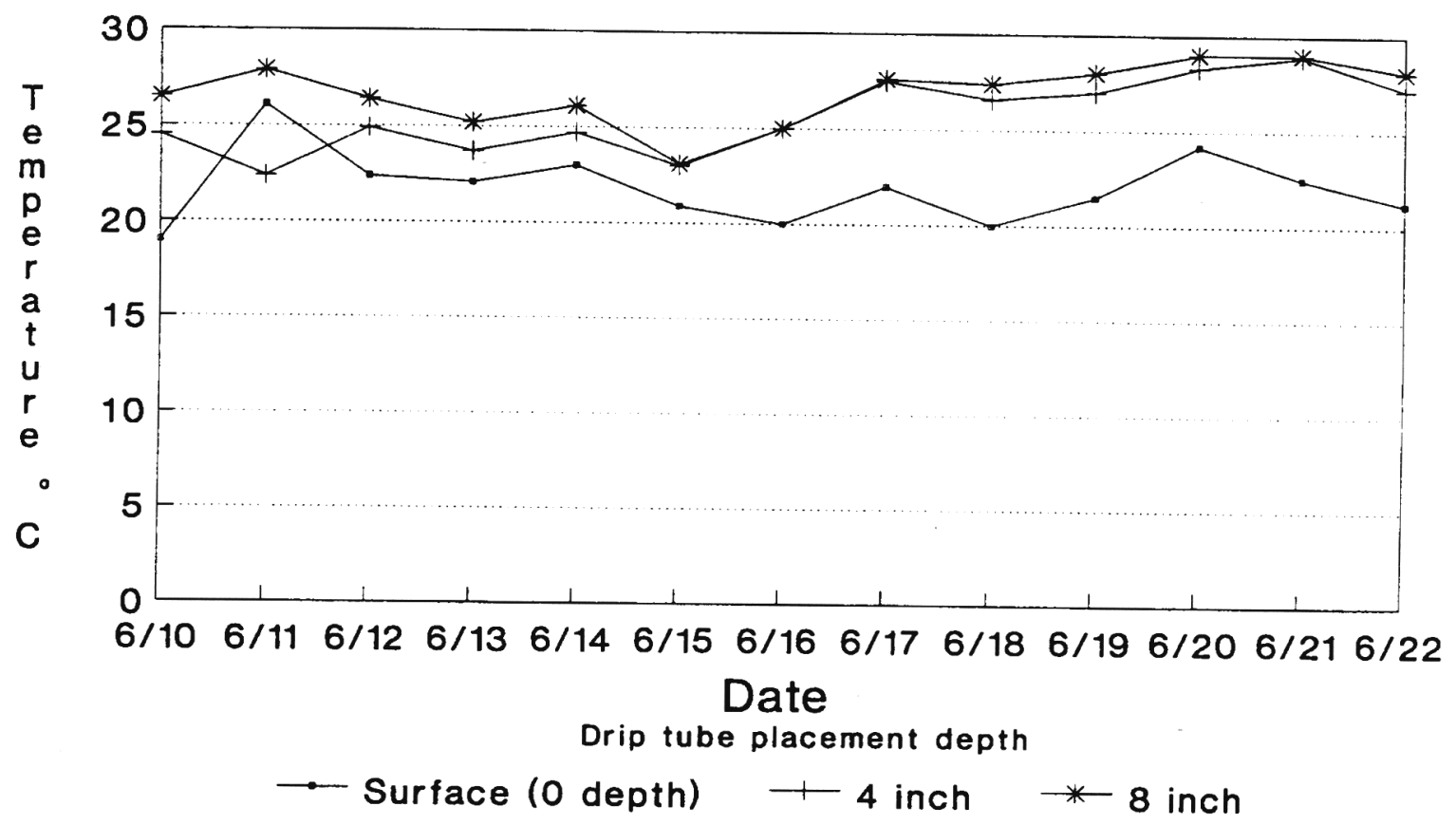

Fig. 2. Daily mean soil temperature at 4-inch depth.

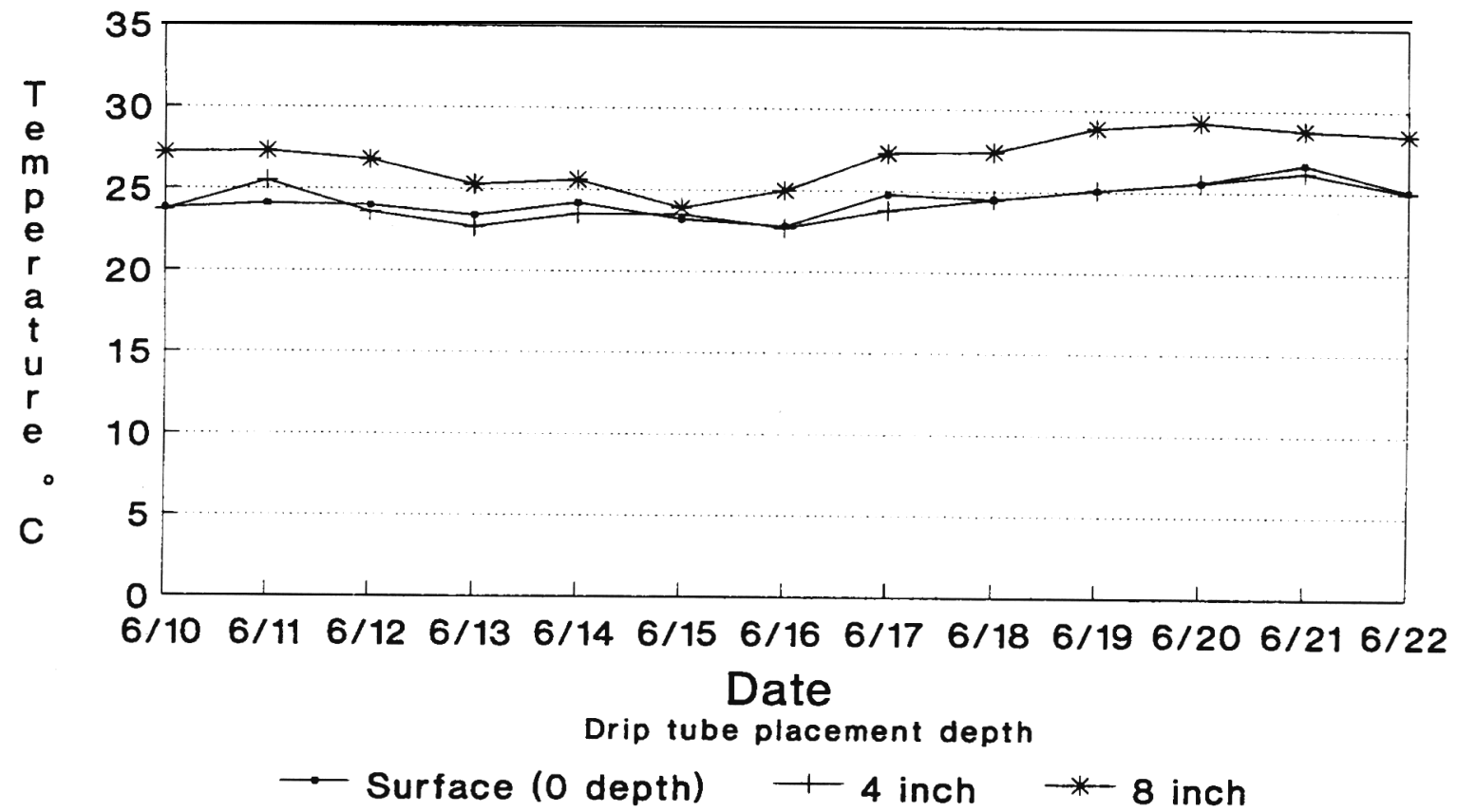

Fig. 3. Daily mean soil temperature at 8-inch depth.

differences in cull potato yield. From visual observations, the soil surface layer for the 8-inch emitter depth treatment was dry most of the time, whereas after irrigation the soil surface layer for the other two treatments was wet. This indicates a potential for increased evaporation with the surface and 4-inch emitter treatments comparedwith the 8 -inch treatment. These differences in soil wetness were probably responsible for differences in soil temperatures (Figs. 1, 2, and 3). The mid- June soil surface temperatures for the S-inch emitter depth treatment were warmer than those for the other two treatments throughout the season. Differences in soil temperature among treatments were greatest at the surface, and decreased with soil depth
(Figs. 1, 2, 3). High soil temperature regimes have been reported as a major cause of reduced yield and quality of potatoes (Box et al., 1963; Manrique, 1985; Yamaguchi et al., 1964). The soil temperature regime difference under each irrigation treatment was probably the cause of significantly higher yields of cull tubers for the 8inch emitter depth treatment. There- 
fore, trickle emitter placement, by directly influencing soil temperature, indirectly influenced evaporation and marketable yield.

\section{Conclusions}

Trickle irrigation at the 8 -inch depth significantly increased cull tuber yield and decreased marketable tuber percentage when compared with emitters placed at the surface or 4-inch depth. However, no significant differences due to irrigation placement were observed for \#1, \#2, marketable, small, or total tuber yields. With equal quantities of water added to all treatments, differences were not a result of this factor. Differences in wetting patterns due to irrigation emitter placement caused differences of soil temperature and evaporative loss. At the 1- and 4-inch depths, soil temperatures were higher for the 8-inch irrigation emitter placement than those of the surface and 4-inch irrigation emitter placements. Associated with increased temperature, evaporative losses were believed to be greater with the 4-inch and surface treatments. The increased temperature is believed to be responsible for the increased misshapen tubers. Therefore, trickle irrigation placement should not only consider application of water but also temperature and evaporative effects. When potatoes are grown in hot climates, trickle irrigation systems must be designed to maintain moderate temperatures within the tuber zone to diminish the occurrence of misshapen tubers.

\section{Literature Cited}

Box, J.E., W.H. Sletten, J. H. Kyle, and A. Pope. 1963. Effects of soil moisture, temperature and fertility on yield and quality of irrigated potatoes in the Southern plains. Agron. J. 55:492-494.

Bucks, D.A., F.S. Nakayama, and A. W. Warrick. 1982. Principles, practices, and potentialities of trickle (drip) irrigation. Adv. Irr. 1:219-298.

Doorenbos, J. and A.H. Kassam. 1979. Yield response to water. Food Agr. Organization Irr. \& Drainage Paper 33.

Doorenbos, J. and W.O. Pruitt. 1977. Guidelines for predicting crop water requirements. Food Agr. Organization Irr. \& Drainage Paper 24.

Epstein, E. 1966. Effect of soil temperature at different growth stages on growth and development of potato plants. Agron. J. 58:169-171.

Federal Register. 1970. United States standards for grades of potatoes. vol. 35; Tide 7. p. 18257-18261.

Hassan, F.A. 1985. Drip irrigation and crop production in arid regions. Proc. 3rd Intl. Drip Irr. Congr. 1:150-155.

Howell, T.A., D.S. Stevenson, F.K. Aljibury, and H.M. Gitlin. 1980. Design and operation of trickle (drip) systems. In:M.E. Jensen (ed.) Design and operation of farm irrigation systems. Amer. Soc. Agr. Eng. p. 663-714.

Manrique, L.A. 1985. Performance of potato (Solanum tuberosum L.) in three tropical soil families as influenced by their temperature regimes. Amer. Potato J. 62:101-110.
Manrique, L.A. and G. Uehara. 1984. A proposed land suitability classification for potato. I. Methodology. Soil Sci. Soc. Amer. J. 48:843-847.

Nakayama, F.S. and D.A. Bucks. 1986. Trickle irrigation for crop production: Design, operation and management. Elsevier, New York.

Phene, C. J. and D. C. Sanders. 1976. Highfrequency trickle irrigation and row spacing effects on yield and quality ofpotatoes. Agron. J. 68:602-607.

Prihar, S.S., N. T. Singh, and B.S. Sanadhu. 1979. Response of crops to soil temperature changes induced by mulching and irrigation, p. 305-315. In: R. Lal and D.J. Greenland (eds.). Soil physical properties and crop production in the tropics. Wiley, New York.

Sammis, T. W. 1980. Comparison of sprinkler, trickle, subsurface, and furrow irrigation methods for row crops. Agron. J. 72:701-704.

Shalhevet, J., D. Shimshi, and T. Meir. 1983. Potato irrigation requirements in a hot climate using sprinkler and drip methods. Agron J. 75:13-16.

Thorne, D. W. and M.D. Thorne. 1979. Soil water and crop production. AVI, Westport, Conn. p. 73-76.

Wierenga, P.J., R.M. Hagan, and E. J. Gregory. 1971. Effects of irrigation water temperature on soil temperature. Agron. J. 63:33-36.

Yamaguchi, M., H. Timm, and A.R. Spurr. 1964. Effects of soil temperature on growth and nutrition of potato plants and tuberization, composition, and periderm structure of tubers. Proc. Amer. Soc. Hort. Sci. 84:412-423. 